\title{
Use of methyl methacrylate, moulded in its paste phase, to fill the orbital cavity of dogs, after exenteration in cases of ophthalmic neoplasias: a report of three cases
}

\author{
Uso do metilmetacrilato, moldado em fase pastosa, no preenchimento da cavidade orbitária de cães \\ submetidos à exenteração, em casos de neoplasias oftálmicas: relato de três casos
}

\author{
Ivia Carmem Talieri ${ }^{1}$ Luiz Eduardo Carvalho Buquera ${ }^{2}$ Arianne Pontes Oriá ${ }^{1}$ \\ Adriana Torrecilhas Jorge Brunelli ${ }^{1}$ Denise Eliza de Almeida ${ }^{1}$ José Luiz Laus $^{3}$
}

\section{- RELATO DE CASOS -}

\section{ABSTRACT}

Methyl methacrylate, acrylic resine for odontologic use, was used to fill the orbital cavity of three dogs which presented retrobulbar, eyeball and eyelid neoplasias extended to the orbital space, respectively. The material was moulded in the orbit before polymerization, while still in its paste phase. In each case, follow-up reports were obtained in the $10^{\text {th }}$ and $40^{\text {th }}$ days and in 18 months after surgery. Complications were not observed and improvement of cosmetic appearance was obtained.

Key words: methyl methacrylate, prosthesis, orbit, neoplasia, dogs.

\section{RESUMO}

O metilmetacrilato, resina acrílica de uso odontológico, foi empregado no preenchimento da cavidade orbitária de três cães, acometidos, respectivamente, por neoplasia retrobulbar, neoplasia do bulbo do olho e neoplasia palpebral com extensão para a órbita. O material foi moldado à órbita, ainda na fase pastosa da auto-polimerização. Em todos os casos, o acompanhamento se deu ao $10^{\circ}$ e $40^{\circ}$ dias e aos 18 meses após a cirurgia. Complicações não foram observadas e efeitos plásticos foram obtidos.

Palavras-chave: metilmetacrilato, prótese, órbita, neoplasia, cães.

\section{INTRODUCTION}

Exenteration is the removal of all orbital tissues, including the eye and its vascular and nervous connections and extraocular muscles. This procedure is indicated in cases of orbital tumors or ocular tumors extending to retrobulbar space (SLATTER, 1990; SPIESS \& WALLIN-HÄKANSON, 1999).

A transpalpebral approach is used after eyelid suture with simple continuos pattern. An incision is performed around the palpebral fissure, approximately $5 \mathrm{~mm}$ from the lid margins. The dissection involves all extraocular muscles, globe, conjunctiva, third eyelid with its lacrimal gland, through the orbicularis oculi and orbital fascia towards the orbital rim. The remaining retrobulbar connective tissue and fat can be excised (SPIESS \& WALLINHÄKANSON, 1999). The disadvantage of this surgery is the cosmetically undesirable orbital concavity, mainly in dolichocephalic and mesocephalic dogs because of their deep orbits ( NASISSE et al., 1988; SLATTER, 1990).

In cases where conventional enucleation has been used, good results have been obtained by

\footnotetext{
${ }^{1}$ Graduate Students, Ophthalmology Section, Veterinary College, São Paulo State University - Via de Acesso Prof. Paulo Donato Castellane s/n - CEP: 14884-900 - Jaboticabal - SP. E-mail: ivia@zipmail.com.br

${ }^{2}$ Graduate Student, Orthopaedic Section, Veterinary College, São Paulo State University, Jaboticabal - SP.

${ }^{3}$ Professor, DVM, PhD, Ophthalmology Section, Veterinary College, São Paulo State University, UNESP- Jaboticabal - SP.

E.mail: jllaus@fcav.unesp.br
} 
implanting orbital prostheses to correct the concavity. The most frequently employed materials are those based in methyl methacrylate (MMA) (NASISSE et al., 1988; MISHIMA et al., 1991; BRYAN \& ENDO, 1992; RAHAL et al., 1996; SPIESS \& WALLINHÄKANSON, 1999) and silicone (HAMOR et al., 1993; SPIESS \& WALLIN-HÄKANSON, 1999). There has been just one report about usage of MMA to fill the orbit after exenteration (GASS, 1969).

Prefabricated MMA spheres (polymerized) were often employed (GASS, 1969; NASISSE et al., 1988; MISHIMA et al., 1991; SPIESS \& WALLINHÄKANSON, 1999). BRYAN \& ENDO (1992) and RAHAL et al. (1996) implanted the MMA in the orbit when it was in its paste phase so that the polymerization would take place inside the orbits of horses and rabbits, respectively. This procedure was performed to mould the MMA in the orbit.

In some horses, BRYAN \& ENDO (1992) observed a complication few months after surgery. There was an atrophy of the orbital tissue around the prosthesis and consequent loss of the cosmetic appearance because of local depression. However, there was adherence in surrounding tissues, avoiding movement of the prosthesis. RAHAL et al. (1996) observed a discreet orbital depression as well; but they also observed good adherence of prostheses in the tissues in all rabbits used in the study 60 days after enucleation.

NASISSE et al. (1988) used polymerized MMA spheres after enucleation. Complications were developed in three of $73 \mathrm{dogs}$ and two of five cats and the implants were removed. The authors attribute the complications to traumatic dislodgment of the sphere, spontaneous extrusion and chronic inflammation. In cats there was fluctuant orbital swelling surrounding the implant.

MMA was also successfully used in orthopaedics to repair fractures of orbital bones (MILLER \& TENZEL, 1969; MILLER, 1970; MAYER et al., 1975).

The purpose of the paper reported here was to evaluate the suitability and cosmetic appearance of MMA orbital prostheses, moulded in its paste to fill orbital cavity of dogs requiring exenteration.

\section{CASE REPORTS}

Three German Shepherd dogs were referred to the Ophthalmologic Section of the School of Agricultural and Veterinary Sciences at São Paulo State University - UNESP - Jaboticabal, SP / Brazil, all of them with histories of severe ophthalmic diseases.
The first case, a 10-year-old female dog, presented melanoma (cytologic analysis) from the limbus, with hemorrhagic discharge for one year. The tumor had extended to the nasal orbital space of the right eye causing strabismus. There was also protrusion of the gland of the third eyelid.

The second dog, a 3-year-old female one, presented exophthalmos, severe chemosis, increased intraocular pressure $(34 \mathrm{mmHg}$ by applanation tonometry) and protrusion of the gland of her left eye's third eyelid. Radiographs revealed space-occupying retrobulbar mass of the left eye, which was confirmed by ultrasonography $(7,5 \mathrm{MHz})$.

The last case, a 11-year-old male dog, had palpebral melanoma of the right eye, which had been previously diagnosed by histological examination. The neoplasia had been excised twice unsuccessfully. After that, it infiltrated to the globe.

Authors decided to make the unilateral exenteration in all three animals because of the irreversible conditions of their eyes. Laboratory exams were performed and the results did not reveal alterations for complete blood count, platelet count and biochemical panel. The first dog's thoracic radiographs revealed nodular interstitial opacities similar to metastasis.

The dogs were submitted to anaesthetic medication, levomepromazine ${ }^{\mathrm{a}}$ (1 $\left.\mathrm{mg} \mathrm{kg}^{-1}, \mathrm{IV}\right)$, propofol $^{\mathrm{b}}\left(5 \mathrm{mg} \mathrm{kg}^{-1}, \mathrm{IV}\right)$, sevoflurane $\mathrm{e}^{\mathrm{c}}$ and oxigen in a closed circuit. The eyelids were approximated using simple continuos suture with 3-0 monofilament nylon ${ }^{\mathrm{d}}$. An elliptic incision on the skin was performed around the palpebral fissure. The dissection involved all extraocular muscles and the conjunctiva. The blood vessels and the optic nerve were transected using 3-0 absorbable ${ }^{\mathrm{e}}$ suture material, and together with the third eyelid, the globe and the neoplasias were then removed. The remaining retrobulbar connective tissue and fat were excised.

The orbital cavities were copiously flushed with sterile saline solution and neomicin ${ }^{\mathrm{f}}\left(1 \mathrm{~g} \mathrm{l}^{-1}\right)$ to remove the remaining tissues and clots. After the cleaning, the acrylic resine ${ }^{\mathrm{g}}$ was moulded in the orbit, but it did not exceed the limits of the orbital rim (Figure 1A). During the resine's polymerization the region was irrigated with cold sterile saline solution to diminish the temperature caused by the exothermic reaction.

The closure of the conjunctiva was performed with 4-0 polyglactin $910^{\mathrm{h}}$ in a continuous pattern and the skin was closed with simple interrupted sutures using 3-0 monofilament nylon. In the postoperative period, the dogs were treated with carprofen ${ }^{\mathrm{i}}$ (2,2 $\mathrm{mg} \mathrm{kg}^{-1}, \mathrm{q} 12 \mathrm{~h} / \mathrm{PO} / 5$ days), ampicillin ${ }^{\mathrm{j}}$ (22 $\mathrm{mg} \mathrm{kg}^{-1}$, 
$\mathrm{q} 8 \mathrm{~h} / \mathrm{PO} / 10$ days $)$ and metronidazole $\left(30 \mathrm{mg} \mathrm{kg}^{-1}, \mathrm{q} 24 \mathrm{~h} /\right.$ $\mathrm{PO} / 10$ days).

A histologic examination of the excised globes and neoplastic masses of each animal was performed. The result for the first dog was confirmed, it revealed limbal melanoma with fusiforms and epithelial cells. The examination of the second animal showed retrobulbar hemangioma with small focus of mineralyzation along with periocular chronic myositis of imune-mediated mechanism. The neoplasia of the third dog was also melanoma, but of palpebral source.

\section{RESULTS AND DISCUSSION}

Follow-up reports were obtained ten days (Figure 1B) and forty days (Figure 1C) after surgery. Eigthteen months follow-up data was gathered by telephone conversations with the owners. The dogs presented satisfactory recovery, without clinical signs of expulsion of the orbital MMA implant.

Orbital space-occupying mass results in the displacement of orbital contents and it causes alteration in their volume or their functions (ANDREW, 1999; SPIESS \& WALLIN-HÄKANSON, 1999). Alterations in volume are presented as exophthalmos with or without pain. The altered function of orbital content can be observed as diminished ocular mobility, strabismus, blindness, anisocoria, episcleral vessels congestion and increase or decrease of lacrimal production (SPIESS \& WALLIN-HÄKANSON, 1999). Other clinical signs associated with retrobulbar or orbital disease include protrusion of the gland of the third eyelid, exposure keratitis, glaucoma, retinal detachment and dysphagia (ANDREW, 1999). In this study, the main alterations were exophthalmos with discreet lagophthalmos, strabismus, protrusion of the gland of the third eyelid, severe conjunctival congestion, severe chemosis, glaucoma and keratitis.

Compression of the third eyelid against the bony orbit by an orbital mass occludes venous drainage, creating protrusion of the its gland and chemosis. Strabismus can be explained by displacement of the globe by neoplasia. Exposure keratitis occurs when the eyelids cannot cover the surface of globe, or if trigeminal or/and facial nerves involvement has ocurred. Glaucoma and retinal detachments result of tissue compression by neoplasia (ANDREW, 1999).

The treatment of orbital neoplasms include exenteration with or without orbitotomy, irradiation and/or chemotherapy (ANDREW, 1999). The authors decided to perform exenteration because it is cheaper than other techniques. In association, they decided to place a MMA orbital implant.

In human beings, some authors cite primary or secondary orbital neoplasias as contraindications for use of orbital implant (RAFLO, 1990). However, in veterinary literature, HAMOR et al. (1990) used silicone implants in 17 animals that had exenteration performed because of orbital neoplasia, resulting in $88 \%$ success. McLAUGHLIN et al. (1995), using intraocular silicone prosthesis implantation in $\operatorname{dog}$ s and a cat with intraocular neoplasias, also to affirm that intraocular neoplasia is not contraindication for use of implants. Hence it follows that there is controversy about usage of implant in neoplasia.

The usage of MMA in medicine and in veterinary have been reported by MILLER \& TENZEL (1969), CHARNLEY (1971), MAYER et al. (1975), MISHIMA et al. (1991), VALADÃO et al. (1994), BEAVER et al. (1996) and RAHAL et al. (1996). Lower cost, practicality and infrequent adverse effects have been indicated as the main justifications. The material has been used as bone cement (SUMNER-SMITH \& WALTERS, 1976; RENEGAR \& GRIFFTHS, 1977; PUTNEY et al., 1983; VALADÃO et al., 1994), maxillofacial prostheses (GAMBLE, 1969; DORTZBACH et al., 1981; VALURI, 1982) and in skull surgery (CAPANNA, 1980). In ophthalmology, the MMA substituted glass and gold in orbital implants and in the manufacture of prostheses (ALLEN \& ALLEN, 1950; MILAUSKAS, 1966; SPIESS \& WALLIN-HÄKANSON, 1999).

Complications due to the usage of MMA include the exothermic reaction, their effects in the surrounding tissue and exposure of tissue to toxic residual monomer (JEFFRIES et al., 1975; GARCIA et al., 1981; TURNER et al., 1981). NASISSE et al. (1988) used the polymerized MMA and, in the same manner, they observed complications as espontaneous extrusion (15 days after surgery) and chronic inflammation (three weeks after surgery) in dogs. In cats, those authors observed fluctuant orbital swelling around the prosthesis.

BRYAN \& ENDO (1992) and RAHAL et al. (1996), employing the conforming intraorbital MMA (paste phase) after enucleation in horses and rabbits, observed loss of the cosmetic appearance due to atrophy of orbital tissue around and behind the prosthesis, resulting in local depression. We believe that this complication did not occur in our study because the MMA was used after exenteration and, therefore, the MMA was in close proximity with the orbital bones. 


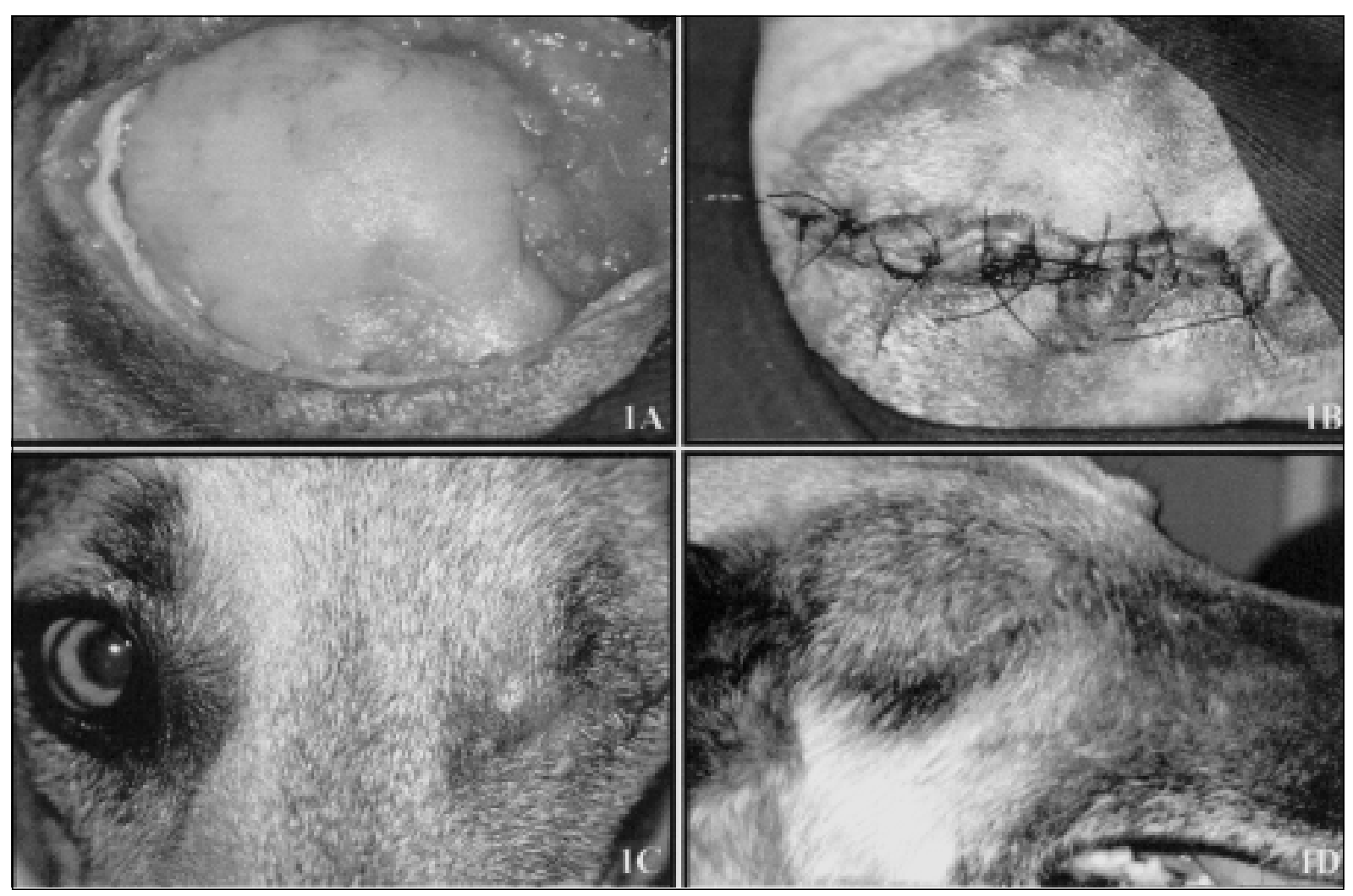

Figure 1 - Photograph of orbital cavity filled with methyl methacrylate moulded in paste in a 10-year-old female German Shepherd dog (A). Closure of skin with simple interruptedsutures uing 3-0 monofilament nylon after filing of orbital cavity with methyl methacrylate in paste phase, in a 10-year-old female German Shepherd dog (B). Cosmetic appearance of 3-year-old female German Shepherd dog on $10^{\text {th }}$ day of postoperative period (C). Cosmetic appearance of 11-year-old female German Shepherd $\operatorname{dog}$ on $40^{\text {th }}$ day of postoperative period (D).

Also, in this study signs of local infection were not observed. It is important to emphasize that the three dogs were treated with antibiotics of broad spectrum and that, according to EDMONSON \& CRENSHAW (1980), the exothermic reaction should contribute to a lower index of infection.

\section{CONCLUSION}

Based in the results, we believe that the MMA in its paste phase, employed to fill the anophthalmic orbital cavity, is a safe, cheap and effective mean of improving the appearance of dogs requiring exenteration.

\section{SOURCES AND MANUFACTERS}

a- NEOZINE: Rhodia Farma

b- PROPOFOL: Cristália

c- SEVO RANE: Abbott

d- SHALON 3-0: Shalon Fios Cirúrgicos Ltda. e- CATEGUTE CROMADO 3-0: Cirumédica

f- NEOBIOTIC - L: Merial Saúde Animal Ltda. g- ACRÍLICO AUTO-POLIMERIZANTE JET: Laboratório Clássico Indústria Brasileira

h- VICRYL 4-0: Ethicon

i- RIMADYL: Laboratórios Pfizer Ltda.

j- AMPICILINA 500 MG CÁPSULAS: Ariston

1- FLAGYL 400: Rhodia Farma

\section{REFERENCES}

ALLEN, J.H.; ALLEN, L. A buried muscle cone implant. I. Development of a tunneled hemispherical type. Archives of Ophthalmology, v.43, p.879-890, 1950.

ANDREW, S.E. Orbital neurofibrossarcoma in a dog. Veterinary Ophthalmology, v.2, n.3, p.141-145, 1999.

BEAVER, D. P. et al. Methylmethacrylate and bone screw repair of seventh lumbar vertebral fracture-luxations in dogs. Journal of Small Animal Practice, v.37, n.8, p.381-386, 1996.

BRYAN, G. M.; ENDO, M. A conforming intraorbital implant in the horse. Equine Practice, v.14, n.9, p.25-28, 1992. 
SLATTER, D. Orbit. In: Fundamentals of veterinary ophthalmology. 2.ed. Philadelphia : Saunders, 1990. p.478-511.

SPIESS, B.M.; WALLIN-HÄKANSON, N. Diseases of the canine orbit. In: GELATT, K.N. Veterinary ophthalmology. 3.ed. Philadelphia : Lippincott Williams \& Wilkins, 1999. p.511-533.

SUMNER-SMITH, G.; WALTERS, E.H. The adjunctive use of methyl metacrylate bone cement in the stabilization of multiple fractures. Journal of American Animal Hospital Association, v.12, p.778-781, 1976.
TURNER, R. C. et al. Molecular and macroscopic properties of PMMA bone cement: free-radical generation and temperature change versus mixing ratio. Journal of Biomedical Materials Research, v.15, p.425-432, 1981 .

VALADÃO, C. A. A. et al. Uso da cerclagem e resina acrílica em fraturas mandibulares dos equiídeos. Ciência Rural, v.24, n.2, p.323-327, 1994.

VALURI, A. J. Maxillofacial prosthetics. Aesthetic Plastic Surgery, v.6, p.159-164, 1982. 